\title{
INOVASI MINUMAN DAN PANGANAN BERBAHAN BAKU BIDARA LAUT (XIMENIA AMERICANA) DAN MANGROVE DARI PESISIR KOTA BATAM
}

\author{
Ramses*1, Erwin Ashari $^{2}$ dan Ramdani ${ }^{3}$ \\ ${ }^{1,2,3}$ Fakultas Keguruan dan Ilmu Pendidikan, Universitas Riau Kepulauan, Batam-Indonesia \\ *E-mail: ramses.firdaus@gmail.com
}

\begin{abstract}
Bidara Laut Plant, Ximenia americana L., is one of coastal vegetation that potentials to be expanded as various healthy drink innovative products and gives a promises to be expanded in the future due to its health benefits and has never been produced. The activity was conducted at Sarang and Mecan Islands, Sekanak Raya sub-district, Belakang Padang district, Batam, in companion with Sarang and Mecan "Kompang" Conservation group. The Activity was started from May up to October 2018. Implementation methods were counseling, training and production practices, demonstration plots, strengthening management and business development through Focus Group Discussion (FGD). This activity has succeeded in improving partner communities' skills in making processed beverages and meals made of Bidara Laut and mangroves fruits. It was a new knowledge for the community in sustainable usage and environmental conservation, especially mangrove resources. Processed innovations types which produced were Bidara Syrup, Bidara Pudot, Bidara Fresh Drinks, Jeruju Stick, Jeruju Layer Cakes, and Komojo Sponge cake, which all these processed mangrove and Bidara products have own exclusivity and beneficial to health. For their sustainability guarantee, mangrove seedling and Bidar Laut X. americana farming were created together with partner community.
\end{abstract}

Keywords - Bidara Laut Syrup, Beverages and meal Innovation

\begin{abstract}
Abstrak
Tanaman Bidara Laut, Ximenia americana L., merupakan vegetasi pesisir yang memiliki potensi untuk dikembangkan menjadi produk inovasi aneka minuman yang berkhasiat kesehatan dan menjanjikan untuk berkembang di masa depan karena memiliki khasiat kesehatan dan belum pernah dilakukan sebelumnya. Kegiatan dilakukan bersama masyarakat yang tergabung dalam kelompok Kompang Konservasi di Pulau Sarang dan Mecan, Kelurahan Sekanak Raya, Kecamatan Belakang Padang, Kota Batam. Kegiatan di mulai dari bulan Mei hingga Oktober 2018. Metode pendekatan program adalah penyuluhan, pelatihan dan praktek produksi, demplot, penguatan managemen dan pengembangan usaha melalui Focus Group Discussion (FGD). Hasil dari kegiatan ini adalah tambahan ketrampilan bagi masyarakat mitra dalam membuat olahan minuman dan panganan berbahan baku bidara dan mangrove. Pengetahuan baru bagi masyarakat dalam pemanfaatan berkelanjutan dan konservasi lingkungan khususnya sumberdaya mangrove. Jenis olahan inovasi yang dihasilkan adalah Sirup Bidara, Pudot Bidara, Minuman Segar Bidara, Stick Jeruju, Kue Lapis Jeruju dan Bolu Komojo yang semua produk olahan mangrove dan bidara ini memiliki kekhasan dan manfaat kesehatan. Untuk jaminan keberlanjutan juga dilakukan upaya konservasi mangrove dan bidara melalui kegiatan pembibitan mangrove dan pembuatan kebun Bidar Laut X. americana bersama masyarakat mitra.
\end{abstract}

Kata Kunci-Inovasi Minuman dan Makanan Bidara Luat

\section{PENDAHULUAN}

Kekayaan dan potensi sumberdaya pesisir yang dimiliki bangsa Indonesia, tidak habishabisnya dalam melahirkan suatu kreativitas dan inovasi baru dalam berbagai bidang, termasuk dalam penyediaan pangan mandiri. Adanya karifan tradisional masyarakat dalam pemanfatan 
potensi sumber daya dalam penyediaan pangan, dapat menjadi kekuatan dalam ketahanan pangan nasional. Menurut Masithoh dan Kusumawati (2016) bahwa masyarakat dapat terlibat dalam program ketahanan pangan dengan memanfaatkan bahan pangan lokal yang ada di sekitarnya. Potensi pangan lokal di Indonesia seharusnya bisa menjadi alternatif bahan utama makanan pokok masyarakat.

Selanjutnya menurut Priyono, et. al., (2010), menyatakan bahwan potensi sumberdaya wilayah dan sumberdaya alam yang dimiliki indonesia memberikan sumber pangan yang beragam, baik pangan sumber karbohitrat, protein maupun lemak, sehingga strategi pengembangan pangan perlu diarahkan pada potensi sumber daya wilayah dan sumber pangan spesifik. Selain meningkatkan ketersediaan pangan, strategi lain untuk meningkatkan ketahanan pangan adalah meningkatkan kerjasama Triple Helix antara universitas, industri dan pemerintah (Rimadianti, Daryanto, dan Baliwati, 2016).

Sumberdaya lokal dalam hal ini diversivikasi pangan berbasis buah mangrove akan membutuhkan buah yang melimpah dan itu bisa diperoleh dengan terus melakukan pelestarian mangrove. Jika upaya rehabilitasi berhasil dan pelestarian terjaga maka bahan baku industri pengolahan mangrove akan cukup tersedia memungkinkan untuk terbentuknya industri pengolahan mangrove dan produksi pangan berbasis buah mangrove lebih kontinyu (Baderan, et. al., 2015; Sabana, 2014).

Tanaman Bidara Laut, Ximenia americana yang memiliki nama synomin Zhizipus littorea merupakan vegetasi pesisir yang memiliki potensi untuk dapat dikembangkan menjadi produk inovasi aneka minuman yang berkhasiat kesehatan dan menjanjikan untuk dapat berkembang di masa depan. Pengolahan buah bidara menjadi sirup, minuman segar lainnya, merupakan inovasi dalam pemanfaatan sumberbada yang belum dilakukan oleh masarakat sebelumnya. Inovasi pembuatan sirup dan minuman siap saji yang berbahan baku buah bidara laut memiliki nilai ekonomi dan marketable karena buah bidara memiliki rasa, aroma yang khas. Selain itu tanaman bidara memiliki khasiat kesehatan yang menjadikan nilai keunggulan tersendiri yang mampu bersaing dengan produk sirup buah dan minuman siap saji lainnya.

Pohan Bidara Laut merupakan tanaman yang tumbuh dan banyak dijumpai di pantai setelah vegetasi mangrove. Namun demikian tanaman ini dapat ditanam jauh dari pantai atau tanpa dipengaruhi air asin (laut). Buah muda berwarna hijau dan setelah masak berwarna kuning. Klasifikasi menurut GBIF Secretariat, (2017); Giesen (2007) Kingdom: Plantae; Phylum: Tracheophyta; Class: Magnoliopsida; Order: Santalales; Family: Ximeniaceae; Genus: Ximenia Plum. ex L.; Species : Ximenia americana L.; Synonym: Ziziphus littorea Teijsm.

Bubur buah dan biji $X$. americana mengandung asam lemak jenuh dan tidak jenuh (Eromosele and Eromosele, 2002; Saeed and Bashier, 2010; Tanko, et al, 2017). Buah X. americana merupakan sumber protein, serat, vitamin, lipid, asam amino dan mineral esensial seperti kalsium, magnesium, kalium, natrium, besi, dan mangan. Kandungan anti-nutrien yang rendah dari buah ini menunjukkan bahwa itu dapat dimanfaatkan sebagai suplemen makanan yang baik untuk formulasi pakan manusia dan hewan. Minyak yang diperoleh dari biji memiliki potensi untuk digunakan sebagai minyak sayur, makanan, farmasi dan aplikasi industri (Tanko, et. al., 2017).

$X$. americana adalah tanaman yang digunakan dalam pengobatan tradisional untuk pengobatan malaria, bisul leproutik dan infeksi kulit asal campuran di bagian utara Nigeria (Ogunleye and Ibitoye, 2003). Kulit pohon X. americana. digunakan dalam pengobatan tradisional sebagai analgesik dan anti-inflamasi (Silva-Leite, et al., 2017). Di Indonesia X. americana, dikenal dengan nama Bidara laut, Bidara, Bidaro, yang dinyatakan sebagai vegetasi pantai. Selain di wilayah pesisir Kota Batam terutama di pulau Mecan (Ramses, 2016), juga ditemukan di pulau Anak Krakatau (Whittaker, et al., 1992), Raja Empat, Papua (Webb, 2005), di pulau Tumbutumbu, Lampeapi dan Wungkolo, Sulawesi Tenggara (Suhardjono 2012).

Lain halnya dengan Bidara, pemanfataan sumber daya mangrove sebagai makanan telah berkembang sejak dulu dan merupakan salah satu kearifan tradisional masyarakat sekitar ekosistem mangrove, namun dalam perekembangannya masih perlu pengembangan lebih lanjut dan perbaikan baik dalam teknik pembuatan maupun pengemasannya, sehingga menjadi alternatif bagi 
pengelolaan ekosistem mangrove secara berkelanjutan (Djajati dan Rosida, 2015). Berbagai jenis buah mangrove yang dapat dijadikan bahan baku panganan yang keberadaannya melimpah di sekitar Pulau Sarang dan Pulau Mecan adalah Pidada (Sonnerita spp), Bakau (Rhizophora sp), Apiapi (Apicenia marina), Tanjang/tumu (Bruguera gimnoriza), Jeruju (Acanthus Ilicifolius), Bakau (Rhizophora sp) (Priyono, et al., 2010; Djajati dan Rosida, 2015). Jebih khusus, Rhizophora mucranata dinyatakan dapat dijakan kerupuk antidiare (Sulistiyati dan Puspitasari, 2015).

Sementara itu, masyarakat sasaran di Pulau Sarang dan Pulau Mecan belum mendapatkan dukungan untuk menjadikan buah bidara dan mangrove menjadi salah satu sumber pangan dan menghasilkan produk yang dapat diproduksi secara ekonomis dan diterima pasar dengan kemasan yang layak dan menarik. Tujuan kegiatan ini adalah untuk memberikan pembinaan kepada masyarakat mitra melalui trasfer pengetahuan, ketrampilan dan teknologi dalam pengolahan buah bidara dan mangrove menjadi produk olahan yang bernilai ekonomi dan ekologis sehingga masyarakat mitra mampu memproduksi produk olahan berupa sirup bidara dan aneka panganan mangrove yang layak dan menjadi alternatif ekonomi bagi masyarakat mitra.

\section{METODE}

Kegiatan dilakukan bersama masyarakat yang tergabung dalam kelompok Kompang Konservasi di Pulau Sarang dan Mecan, Kelurahan Sekanak Raya, Kecamatan Belakang Padang, Kota Batam. Kegiatan di mulai dari bulan Mei hingga Oktober 2018. Metode yang digunakan dalam kegiatan ini adalah pelatihan dan penyuluhan, dan praktek produksi serta. penyuluhan, pelatihan dan praktek produksi, demplot, penguatan managemen dan pengembangan usaha melalui Focus Group Discussion (FGD). Pembuatan aneka sirup bidara dikembangkan berdasarkan teknik pembuatan sirup pada umumnya. Sedangkan pembuatan aneka panganan mangrove, penanganan bahan baku, pada kegiatan ini merujuk pada Priyono, et. al., (2010); Hakim dan Saraswati, (2007) dan beberapa bahan dan cara dilakukan modifikasi. FGD dipandang sangat efektif untuk menggali persepsi kelompok dampingan mengenai masalah tertentu yang akan menjadi agenda pembahasan terutama dalam penguatan managemen dan pengembangan usaha pasca pelatihan atau kegiatan. Pada dasarnya FGD digunakan agar orang atau kelompok terdorong untuk membuka diri menyampaikan pendapat secara bebas.

\section{HASIL DAN PEMBAHASAN}

\section{Tanaman Bidara}

Bidara merupakan tanaman berkayu sebagai semak belukar, tumbuh tepat di belakang pantai di tanah berbatu atau berpasir dan di tepi hutan bakau di atas tanah berpasir, tinggi berkisar 5-7 meter. Tanaman ini memiliki duri pada cabang atau ranting seperti tanaman jeruk, dan memiliki buah berbentuk oval. Buah muda berwarna hijau dan buah yang masak berwarna kuning dengan ukuran buah 2-3 cm. Memiliki daging buah yang lunak (jika sudah masak). Kulit buah menyatu dengan daging buah, dan dalam daging buah terdapat biji yang memiliki cangkang/tempurung. Menurut Hine and Eckman, (1993) X. americana terdapat di daerah kering dan semi kering. Propagasi dapat dilakukan dari biji dan stek. Perbanyakan vegetatif sangat mungkin dilalukan. Pohon menghasilkan secara alami dari biji dan semak belukar. Upaya pembibitan dilaporkan hanya ada sedikit pengalaman dengan membesarkan bibit dan menanamnya namun sangat mungkin. Pada daerah yang baik untuk siklus pertumbuhan, pohon bidara laut menghasilkan buah setelah tahun di tahun ke 3 atau setelahnya. Pohon bidara laut ini berbunga dan berbuah sepanjang tahun tidak bergantung pada rezim iklim. Benih dikumpulkan pada bulan Juli dan Agustus. Sistem manajemen untuk regenerasi di hutan alam sangat jarang, jadi perlindungan parsial dari habitat aslinya dapat meningkatkan regenerasi alami.

Kulit batang coklat keabu-abuan. Daunnya sederhana, diatur secara spiral, 2,5-5 (-10) cm dengan 1,2-2,5 (-6) $\mathrm{cm}$, biasanya berbentuk bulat panjang tetapi bervariasi, dengan tangkai pendek 3-5 (-7) $\mathrm{mm}$; daun saraf 3-5 (-7) pasang. Bunga-bunga kecil, berwarna putih kehijauan dengan tangkai pendek $(1,5 \mathrm{~cm})$ atau malai, terletak di aksis, dengan 3-9 bunga. Kelopak mata mirip 
DINAMISIA - Jurnal Pengabdian Kepada Masyarakat Vol. 2, No. 2 Desember 2018, Hal. 197-204

dengan 4-5 gigi, 0,5-1,5 mm; kelopak 4 (-5), rekurved, (5-) 8-10 (-12) mm dengan 1,5-2 mm, tebal berbulu di bagian dalam; benang sari 8 (10) (Giesen, at. al., 2007). Spesies Ximenia americana L., termasuk kedalam keluarga Olacaceae, umumnya dikenal sebagai plum liar, plum asam biru dan kacang tallow. Ini menyebar atau, lebih jarang, semak berduri yang berebut atau pohon kecil hingga $6 \mathrm{~m}$, biasanya kurang dari $4 \mathrm{~m}$. Cabang-cabang yang biasanya melengkung ke bawah sering dipersenjatai dengan duri-duri lurus. Buah-buahan, hingga $3 \mathrm{~cm}$ panjang, oval, mengkilap. Hijau muda, berubah kuning, oranye atau merah saat pemasakan. Buahnya adalah buah edible kuningmerah yang berbentuk oval, berdiameter sekitar $2,5 \mathrm{~cm}$ dan mengandung satu biji endospermik besar di dalam pulpa hijau yang mengandung embrio kecil di dekat testa yang tipis (Feyssa, et al. 2012).

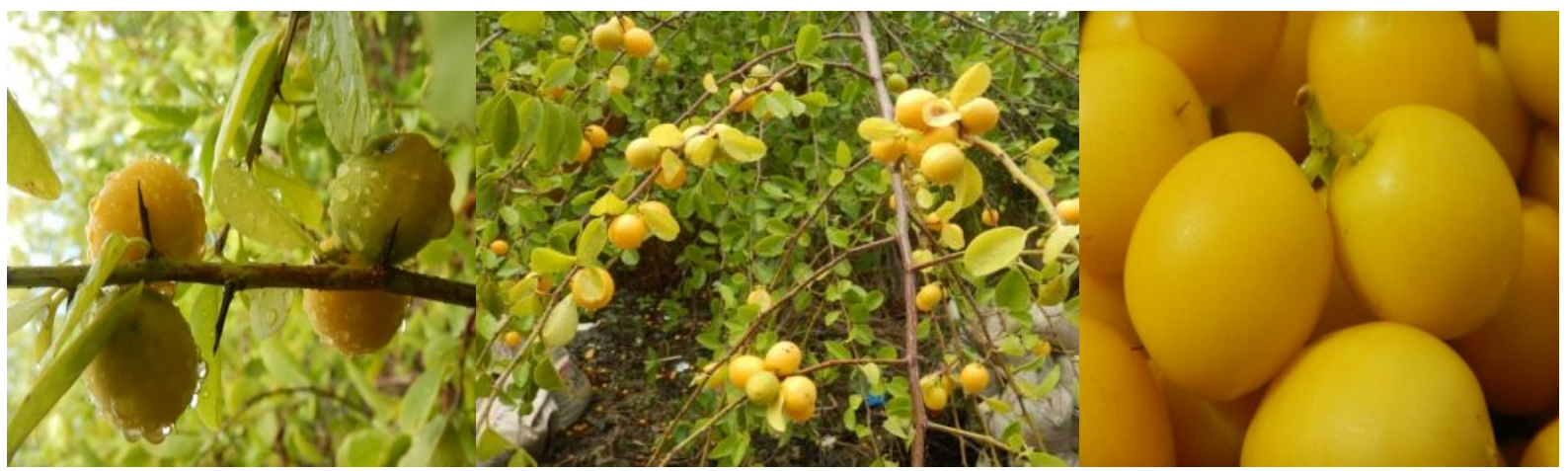

Gambar 1. Buah Bidara Laut (Ximenia americana) yang sudah masak.

\section{Tanaman Jeruju}

Jeruju (Acanthus ilicifolius) merupakan jenis tanaman merambat yang bisa tumbuh hingga setinggi 2 meter pada kondisi lingkungan ideal. Banyak ditemukan di tanah/daratan berpasir setelah mangrove sejati. Dibeberapa tempat, seperti Thailand, Indonesia daun jeruju di jatikan the herbal karena memiliki khasiat obat. Jenis yang tidak berduri biasanya dijadikan makanan ternak. Nilai nutrisinya belum banyak diketahui masyarakat pesisir, khususnya Kota Batam.

Jeruju merupakan tanaman vegetasi mangrove yang tumbuh secara alami di daerah pesisir. Selain berfungsi secara ekologi, tanaman jeruju telah dimanfaatkan menjadi sumber makanan dan minuman. Menurut Prayogo, et al., (2010) daun jeruju dapat dimanfaatkan menjadi kerupuk dan juga dapat dijadikan produk minuman jeruju dan penambahan daun pandan positif mengandung senyawa flavonoid dan fenol berdasarkan uji kualitatif flavonoid (Najar, Thamrin dan Asyik, 2018). Jeruju juga dinyatakan sebagai tanaman yang mengandung senyawa antibakteria (Saptiani, Prayitno, dan Anggoro, 2013)

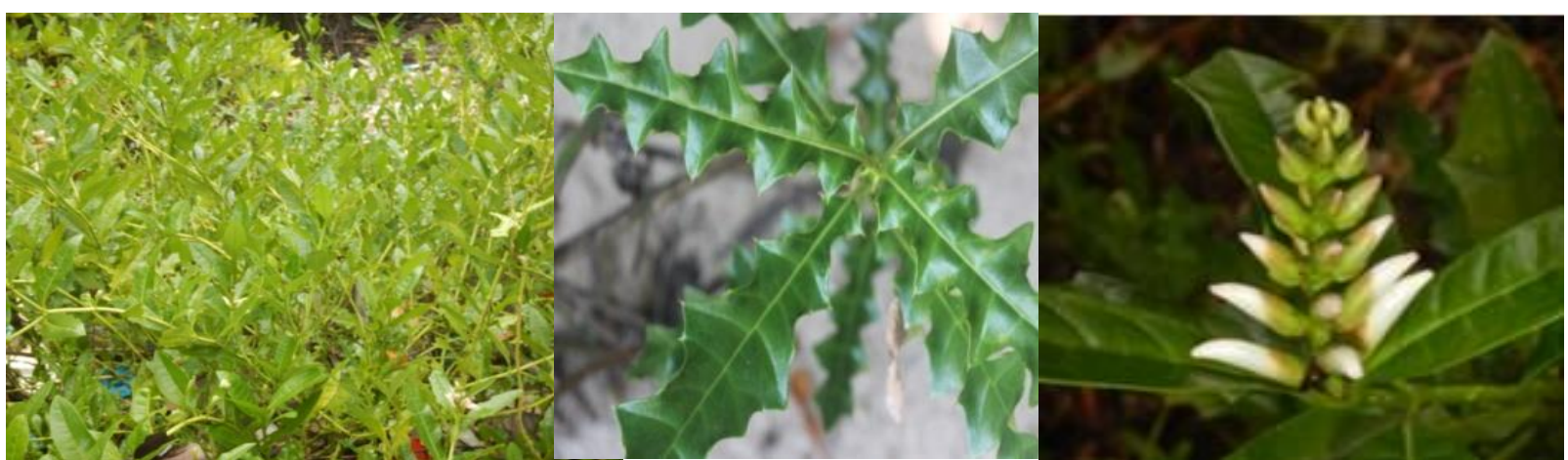

Gambar 1. Tanaman Jeruju (bentuk Daun dan Bungan).

\section{Pembuatan Aneka Minuman Bidara}

Sebagaimana pembuatan sirup buah lainnya, dalam pembuatan sirup dan minuman berbahan baku buah bidara laut dapat mengunakan buah yang sedikit matang sampai buah yang matang 
sempurna. Dalam proses penyiapan, tidak memerlukan penanganan khusus sebagaimana penyiapan buah mangrove, seperti api-api dan lainnya yang memerlukan penanganan khusus sebelum dapat dimanfaatkan. Pembuatan sirup dan minuman berbahan baku bidara adalah sebagai berikut:

\section{Sirup Bidara}

Bahan pembuatan sirup bidara terdiri dari: 1 liter sari Bidara (1/2 kg buah), $3 \mathrm{~kg}$ gula pasir, $1 / 2$ liter sari jeruk nipis ( $1 / 2 \mathrm{~kg}$ jeruk), 1 ruas jari kayu manis. Cara pembatannya adalah sebagai berikut: Untuk mendapatkan sari buah bidara laut, buah yang sudah dibersihkan direbus dengan mengunakan air yang bersih (dianjurkan untuk mengunakan air mineral), tambahkan sari jeruk dan kayu manis secukupnya, biarkan hingga mendidih. Dalam masa berebusan, lakukan pelumatan buah, agar daging buah berpisah dari bijinya. Api dimatikan. Masukkan gula dan aduk sampai cair. Nyalakan api (api sedang) rebus sampai mendidih. Lalu api dimatikan, tunggu beberapa menit. Kemudian rebus kembali. Ulang sebanyak 3 kali. Saring dengan saringan kasa halus. Dinginkan dan siap untuk dikemas atau di gunakan sebagai sirup. Untuk memperpanjang masa pengunaan simpan dalam lemari es dan lebih nikmat bila di konsumsi dalam bentuk minuman dingin.

\section{Pudot Bidara}

Bahan untuk membuat pudot bidara adalah 2.5 liter air mineral, $1 / 2$ liter jus bidara $(1 / 2 \mathrm{~kg}$ buah bidara), 2 sendok makan maizena, 1 Saset nutrijel (15 gram), 1 kaleng susu kental manis putih dan nata de coco potongan kecil secukupnya. Cara pembuatan pudot bidara adalah sebagai berikut: Gabungkan semua bahan pada wadah (kecuali nana de coco), rebus hingga matang sambil di adukaduk. Setelh mendidih masukan nata de coco. Matikan api. Masukkan dalam kemasan pada saat masih hangat (bukan panas). Dinginkan dan selanjutnya kemasan ditutup setelah dingin.
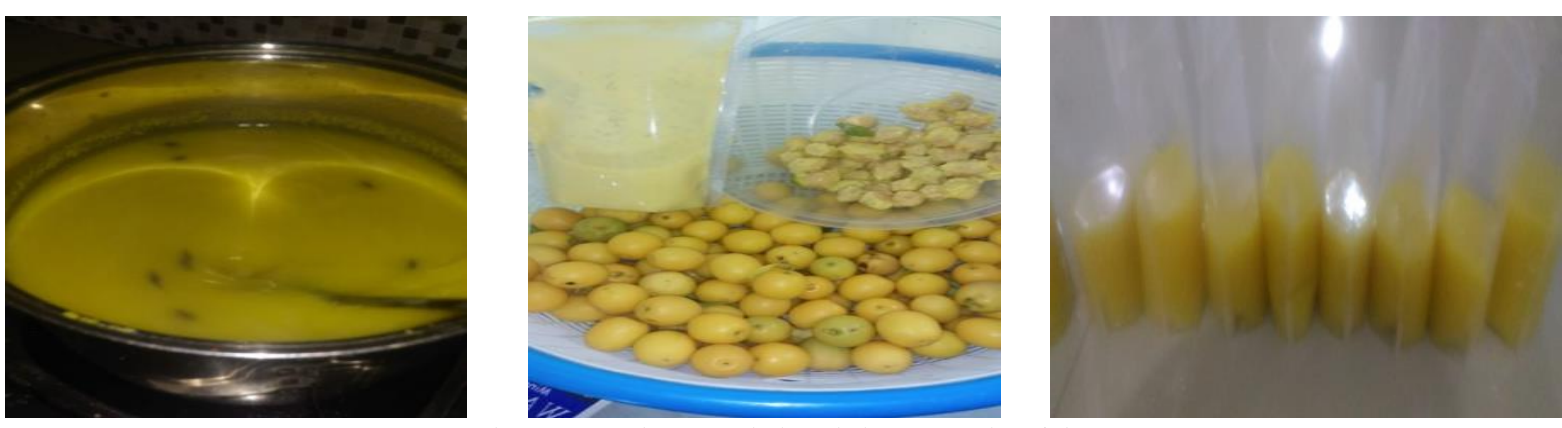

Gambar 2. Pudot Praduk Olahan Buah Bidara

\section{Aneka Panganan Mangrove}

\section{Stick Jeruju}

Bahan untuk membuat Stick Jeruju adalah 1 ons jeruju halus, 1 ons ikan/udang halus, 1 ons maizena, 1 ons tepung bruguera/tumu (bisa diganti tepung terigu), 1 ons mentega, 1 ons tepung tapioka, 1 sendok makan ketumbar halus, 2 butir telur, 1 sendok makan garam, $100 \mathrm{cc}$ air mineral, $1 / 2$ sendok merica bubuk, 1 sendok makan gula, 1 ons kacang tanah halus, 1 sendok baking powder, daun jeruk halus, mingak goreng (pengorengan). Adapun cara membuatnya mengikut stap berikut: Semua bahan dicampus, aduk hingga menyatu (kalis). Lalu cetak berbentuk stick pakai ampia dan digoreng hingga matang. Dinginkan dan stick sudah dapat dikemas atau disajikan.

\section{Kue Lapis Jeruju}

Bahan untuk membuat Kue Lapis Jeruju adalah 300 gram tepung beras, 1/4 liter ekstrak jeruju tambah pandan secukupnya, 150 gram tepung kanji, 350 gram gula pasir, $750 \mathrm{ml}$ santan kental yang sudah di rebus, Garam secukupnya. Cara pembuatan kue lapis jeruju adalah: Masak santan sampai mendidih. Siapkan wadah dan masukkan tepung bers, tepung kanji dan garam secukupnya dan tambahkan gula pasir. Aduk sampai rata. Masukan sedikit demi sedikit santan yang tela 
direbus. Lalu aduk kembali (adonan tidak boleh terlalu kental agar hasilnya tidak keras). Bagi adonan menjadi 2 baian. Satu bagiannya tambahkan ekstak daun jeruju. Lalu kukus adonan secara berlapis.

\section{Bolu Komojo}

Bolu komojo merupakan kue khas melayu di Kota Batam dan Kepri, yang disajikan dalam upacara budaya dan hari istimewa atau hari besar, yang memerlukan banyak tepung dalam pembuatannya. Alternatif tepung dari mangrove adalah tepung tumu (Bruguiera gymnorhiza). Adapun cara pembuatannya adalah: sediakan 250 gram tepung Tumu, 250 gram terigu, 8 butir telur, 1 sendok teh pasta, 1 sendok teh soda kue, 1 sendok teh vanili, 250 gram mentega. Cara pembuatan bolu komojo adalah sebagai berikut: Telur dan gula kocok sampai mengembang. Kemudian masukkan buah api-api dan terigu beserta pasta, soda kue, mentega dan vanili. Setelah itu masukkan ke dalam loyang kemudian dibakar.

\section{Kemasan dan Merk Produk}

Direncanakan adanya 3 (tiga) jenis minuman berbahan baku buah bidara, 3 jenis produk panganan berbahan baku mangrove. Berikut dalah bentuk-bentuk merk kemasan yang akan dikembangkan sebagai awal pengembangan panganan dan minuman dari mangrove dan bidara laut dari Kota Batam.
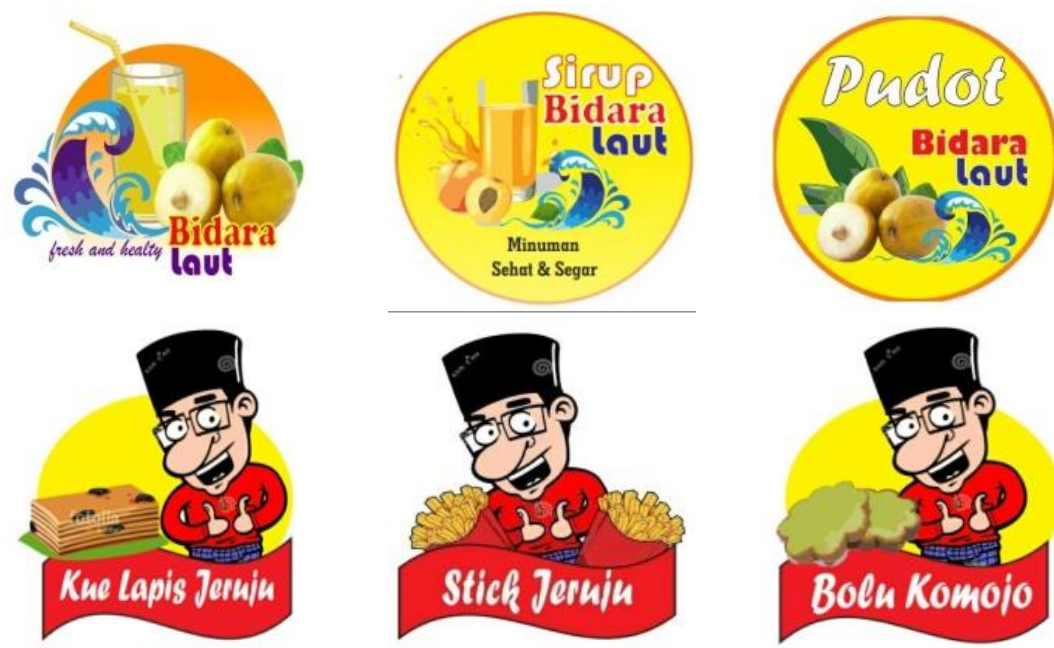

Gambar 3. Merk Produk Unggulan

\section{KESIMPULAN}

Potensi Biara Laut sangat layak dan menjanjikan dikembangkan untuk ketahanan pangan dan sebagai penopang ekonomi keluarga masyarakat pesisir. Bertambahnya ketrampilan masyarakat mitra dalam membuat olahan minuman dan panganan berbahan baku bidara dan mangrove. Meningkatnya pengetahuan bagi masyarakat dalam pemanfaatan berkelanjutan dan konservasi lingkungan khususnya sumberdaya mangrove. Jenis olahan inovasi yang dihasilkan adalah Sirup Bidara, Pudot Bidara, Minuman Segar Bidara, Stick Jeruju, Kue Lapis Jeruju dan Bolu Komojo (Bakau Tumu), yang semua produk olahan mangrove dan bidara ini memiliki kekhasan dan manfaat kesehatan. Untuk jaminan keberlanjutan juga dilakukan upaya konservasi mangrove dan bidara melalui kegiatan pembibitan mangrove dan pembuatan kebun Bidar laut bersama masyarakat mitra. 
DINAMISIA - Jurnal Pengabdian Kepada Masyarakat Vol. 2, No. 2 Desember 2018, Hal. 197-204

\section{UCAPAN TERIMA KASIH}

Terima kasih kepada Kementerian Riset, Teknologi dan Pendidikan Tinggi yang telah mendanai Program Kemitraan Masyarakat (PKM) ini melalui Hibah dengan Kontrak Pengabdian 001/KP-PKM/LPPM/ UNRIKA/IV/2018.

\section{DAFTAR PUSTAKA}

[1] Baderan, D.W.K., Hamidun, M.S., Lamangandjo, C., dan Retnowati, Y. 2015. Diversifikasi produk olahan buah mangrove sebagai sumber pangan alternatif masyarakat pesisir Toroseaje, Kabupaten Pohuwato, Provinsi Gorontalo. Pros Semnas Masy Biodiv Indon. Volume 1, Nomor 2:347-351. DOI: 10.13057/psnmbi/m010230

[2] Djajati, S. dan Rosida, D.F., 2015. Pengembangan Produk Olahan Mangrove dan Perikanan di Kawasan Pantai Wonorejo Surabaya. Prosiding Seminar Nasional "Research Month" 2015. "Sinergi Hasil Penelitian dan Pengabdian kepada Masyarakat untuk Menumbuhkan Kapasitas Inovasi di Bidang Teknologi, Pertanian, Sosial dan Ekonomi". Halaman 381-387.

[3] Eromosele, C. \& Eromosele, I., 2002. Fatty acid compositions of seed oils of Haematostaphis barteri and Ximenia americana. Bioresour Technol, 82(3), 303-304.

[4] Giesen, W., Wulffraat, S., Zieren, M., and Scholten, L., 2007. Mangrove Guide Book For Southeast Asia. FAO and Wetlands International, Dharmasarn Co. Ltd. 769 pp.

[5] GBIF Secretariat. 2017. GBIF Backbone Taxonomy. Checklist dataset. https:// doi.org/10.15468/39omei accessed via GBIF.org on 2018-07-29.

[6] Hakim, T. L., Saraswati, B., 2007. Resep panganan dari tumbuhan mangrove. MAP-Indonesia dan Pusat Studi Asia Pasifik, UGM. Yokyakarta. 38 hal.

[7] Hines, D.A., and Eckman, K., 1993. Indigenous Multipurpose Trees of Tanzania: Uses and Economic Benefits for People. Food and Agriculture Organization of the United Nations. Rome. 276 p.

[8] Masithoh, R.E., dan Kusumawati, H. 2016. Pemberdayaan Ibu Rumah Tangga dalam Implementasi Teknologi Pengolahan Sumber Karbohidrat Nonberas dan Penganekaragaman Pangan Nonterigu untuk Mendukung Ketahanan Pangan. Indonesian Journal of Community Engagement Vol. 02 (01):89-100

[9] Najar, Tamrin dan Asyik, N., 2018. Ajian Pengembangan Pangan Fungsional Minuman Daun Jeruju (Acanths Ilicifolius) Dengan Penambahan Daun Pandan (Pandanus amaryllifolius Roxb) Terhadap Karakteristik Organoleptik Dan Aktivitas Antioksidan. J. Sains dan Teknologi Pangan. Vol. 3(2):1237-1246.

[10] Ogunleye, D.S. \& Ibitoye, S.F., 2003. Studies of antimicrobial activity and chemical constituents of Ximenia americana. Tropical Journal of Pharmaceutical Research, 2(2), 239-241.

[11] Priyono, A., Ilminingtyas D, Mohson, Yuliani LS, Hakim T.L., 2010. Beragam Produk Olahan Berbahan Dasar Mangrove. Kesemat. Semarang.

[12] Ramses, 2016. Inventarisasi Karagaman Jenis Flora Mangrove Di Pulau Mecan Kota Batam. Simbiosa, Vol. 5(2): 126-134

[13] Rimadianti, D. M.A., Daryanto, A., Baliwati, Y.F., 2016. Strategi peningkatan ketahanan pangan Dinas pertanian dan ketahanan pangan Kota tangerang selatan. J. Gizi Pangan. 11(1):75-82

[14] Sabana, C., 2014. Kajian Pengembangan Produk Makanan Olahan Mangrove. Jurnal Ekonomi dan Bisnis. Volume 14 (1):40-46.

[15] Saeed, A. E. M,. R S M Bashier. 2010. Physico-chemical analysis of Ximenia americana.L seed oil and structure elucidation of some chemical constituents of its seed oil and fruit pulp. Journal of Pharmacognosy and Phytotherapy. 2(4):49-55. 
DINAMISIA - Jurnal Pengabdian Kepada Masyarakat Vol. 2, No. 2 Desember 2018, Hal. 197-204

[16] Saptiani, G., Prayitno, S. B., dan Anggoro, S. 2013. Potensi Antibakteri Ekstrak Daun Jeruju (Acanthus ilicifolius) Terhadap Vibrio harveyi Secara In Vitro Jurnal Kedokteran Hewan. Vol. 7(1): 17-20

[17] daSilva-Leite, K. E. S., Assreuy, A. M. S., Mendonca, L. F., Damasceno, L. E. A., Queiroz, M. G. R. de, Mourao, P. A. S. ...............Pereira, M. G., 2017. Polysaccharide rich fractions from barks of Ximenia americana inhibit peripheral inflammatory nociception in mice Antinociceptive effect of Ximenia americana polysaccharide rich fractions. Revista Brasileira de Farmacognosia, 27(2017), 339-345.

[18] Suhardjono. 2012. Keanekaragaman Tumbuhan Vegetasi Hutan Mangrove Di Tumbu-Tumbu, Lampeapi Dan Wungkolo, Pulau Wawonii, Sulawesi Tenggara. Berita Biologi 11(2):221-230.

[19] Sulistiyati T. D., dan Puspitasari, Y. E., 2015. Kerupuk Mangrove antidiare dari buah bakau Rhizopora mucronata. JIAT, Vol 1(1): 82-87.

[20] Tanko E., Ajai A. I., Lafiya -Araga R. A., Dauda B. E. N., Mathew J. T., Omozokpia J., 2017. Physico-chemical, Fatty Acid Profile and Amino Acid Composition of the Fruit Pulp and Seeds of Ximenia americana L. (Tallow Plum) Obtained in Niger State, Nigeria. International Journal of Food Chemistry, 1(2), 30-34.

[21] Webb, C.O., 2005. Vegetation of the Raja Ampat Island, Pupua, Indonesia. Available at: http://camwebb.info/files/webb2005 raja ampat veg.pdf\%0A\%0A.

[22] Whittaker, R.J. et al., 1992. Ecological aspects of plant colonisation of the Krakatau Islands. GeoJournal, 28(2), pp.201-211. 